\title{
The International Technology Diffusion Effect of Cross- Border and Cooperative Patents
}

\author{
C.-L. Chang $^{\text {ab }}$, M. McAleer ${ }^{\text {cde }}$ and J.-T. Tang ${ }^{\text {a }}$ \\ ${ }^{a}$ Department of Applied Economics, National Chung Hsing University, Taiwan. \\ ${ }^{b}$ Department of Finance, National Chung Hsing University, Taiwan. \\ ${ }^{c}$ Department of Quantitative Finance, National Tsing Hua University, Hsinchu, Taiwan \\ ${ }^{d}$ Econometric Institute, Erasmus School of Economics, Erasmus University Rotterdam, The Netherlands. \\ e Tinbergen Institute, The Netherlands \\ Email: changchialin@nchu.edu.tw
}

\begin{abstract}
With the advent of globalization, economic and financial interactions among countries have become widespread. Given technological advancements, the factors of production can no longer be considered to be just labor and capital. In the pursuit of economic growth, every country has sensibly invested in international cooperation, learning, innovation, technology diffusion and knowledge. In this paper, we use a panel data set of 40 countries from 1981 to 2008 and a negative binomial model, using a novel set of cross-border patents and joint patents as proxy variables for technology diffusion, in order to investigate such diffusion. The empirical results suggest that, if it is desired to shift from foreign to domestic technology, it is necessary to increase expenditure on R\&D for business enterprises and higher education, exports and technology. If the focus is on increasing bilateral technology diffusion, it is necessary to increase expenditure on R\&D for higher education and technology.
\end{abstract}

Keywords: International Technology Diffusion, Exports, Imports, Joint Patent, Cross-border Patent, R\&D, Negative Binomial Panel Data 


\section{INTRODUCTION}

With advances in technology and communications, the boundaries between countries have become blurred. In the increasingly globalized market, multinational corporations are, through free trade and foreign direct investment, exchanging capital, goods, services and knowledge across borders. As a result, countries have become increasingly dependent economically on each other, as both enterprises and the countries themselves form competitive and cooperative relationships. For these reasons, to remain competitive in international markets, multinational companies are actively engaging in technology reform and innovation at the international level. This means that the key elements of business growth comprise not only traditional capital, equipment and labor, but also knowledge and the ability to employ and innovate in the area of technology. In the current globalized economic environment, these factors are of considerable importance to increasing business productivity and international competitiveness.

As each country has different levels of expertise and knowledge, multinational enterprises engage in international cooperation to acquire innovation technology and knowledge. By keeping their costs of research and development (R\&D) relatively low, they are enhancing their ability to adapt to international markets. In order to achieve the effects of technological progress, these enterprises are making every effort to acquire technology and to innovate. Thus, the competition taking place among economic activities at the international level indirectly results in the international spread of technology. In addition to the technology spillovers occurring as a result of the technology embodied in the trade in goods and services, these international technology spillover channels also include technology spillovers arising from purchases and sales of disembodied technology. Technology diffusion can also be referred to as knowledge spillover. When defining knowledge and technology, it can be difficult to distinguish between them. Knowledge is typically produced by universities and research institutions. After application in the market place, and undergoing research and development, if knowledge has any economic value, it can then be called technology. At this point, knowledge will be able to contribute to a country's economic growth.

In the current economic environment, a country's ability to innovate has become an important factor in enhancing business productivity and economic growth. The higher is the degree of national innovation, the more developed will be the technology and knowledge that the country itself owns. However, through international cooperation, a country may possibly obtain greater resources to enhance economic growth. In this paper, we use patent cooperation as an indicator to measure international cooperation.

This paper uses patent data to evaluate international innovation activities in order to obtain a technology diffusion trajectory. Patents constitute the output of a country's innovation activities. As patents are knowledge or technology for which application is made, and approval is obtained from the patent authorities, others do not have the right to steal them or engage in plagiarism in relation to them. In this sense, patents have economic value. Based on the premise that patents are the output of innovation, patents can be used to measure a country's creativity. In particular, by means of the information provided by the patent documents, it is possible to investigate the trajectory of technology flows in the process of innovation. In this way, it can be determined whether innovation is diffused through $R \& D$ cooperation, or through the movement of technology across borders, or from one enterprise to another. Based on the above, this paper analyses the international technology spillover effects for merchandise trade through embodied technology, as well as those effects based on the trade in disembodied technology. We use different patent characteristics to examine the effect of international spillovers for a sample of 40 countries, classified as Organization for Economic Co-operation and Development (OECD) countries and non-OECD countries.

\section{LITERATURE}

Technological spillovers can be used to advantage by enterprises, which will then generate positive external effects, which leads to an entire batch of enterprises within the cluster achieving technological progress, to changes in product design, and to production systems being upgraded or to the development of new customer-based results. The primary channels are international trade and foreign direct investment, and it is through such international trade and foreign investment behavior that a country will promote the international flow of technology. In addition, international technology spillovers are effective for enhancing the productivity of less developed countries. The use of technology spillover externalities depends mainly on the countries being able to understand and explain the knowledge and technology. This means that education is extremely important for human capital. The literature focuses on three main channels of technology diffusion in relation to merchandise trade, technology trade and individual learning capability. 


\section{DATA AND VARIABLES}

In this paper, 40 countries are considered for 1981-2008, with countries divided into OECD and non-OECD countries. As the OECD was established in 1961, we divide the countries into those that joined as founding members in 1961 and those that acceded to OECD later. Details of the countries comprising the sample and the year in which they joined the OECD are available on request. Patents are the output of innovation activities. Patent cooperation can be used to measure the extent to which countries cooperate with each other in regard to innovation, and refers to the internationalization of the diffusion of knowledge and invention activities. Moreover, the international patent cooperation emphasized is concerned with the information contained within the patent documents, which indicates the names of the inventor and the applicant. In most cases, the applicant may be an enterprise, an organization, a university or a research office, and in some cases an individual. The applicant has ownership of the patent. The patent document includes the residential addresses of both the inventor and the applicant, and it is from this information that the nationality of the inventor and the applicant can be ascertained. If the inventor and the applicant are from different countries, it is possible to track the flow of knowledge internationally through both of these countries. According to the OECD (2008), the number of patents based on collaboration between inventors and applicants of different nationalities have accounted for an increasingly large share of all patents in recent years. There are two main reasons , namely "creation of knowledge" and "search for knowledge". We use the numbers of international patent cooperation as proxy variables of technology diffusion. Two types of international patent cooperation serve as dependent variables, namely Cross-border patents and Jointly-invented patents. Both types of international patent cooperation are the numbers of patents approved for 1981-2008 by the USPTO.

For international trade, we use imports as well as exports of goods and services of all domestic industries to examine the relationship between imports and exports of patents and international trade, and international investment. This paper uses expenditure on and income from technology trade to measure the extent to which a country uses foreign technology and sells technology. For the innovation input, the paper uses the country's gross expenditure on R\&D to measure the country's R\&D input. We also subdivide the country's gross expenditure on R\&D into three categories, namely government agencies' expenditure on R\&D, business organizations' expenditure on R\&D, and R\&D expenditure by higher education. This will allow discussion of the R\&D input in greater detail in different domains, and an analysis of the impact of expenditure on R\&D on patents. Finally, to examine whether differences exist among OECD member countries, we use a dummy variable. The details of the explanatory variables are available upon request.

\section{EMPIRICAL MODEL}

The patent data used here consist of count data, the data type being panel data. The negative binomial model is chosen for estimation in this paper. Before estimation, it is necessary to pay attention to two limitations of the model, as given in below. The data used here are count data and overdispersion must exist. This means that the variances of the explanatory variables are greater than the corresponding means. For the count data for each of the three patent variables, the variances are greater than their means, so that overdispersion exists. The problem of zero inflation is not inherent in the data. By zero inflation is meant that the count data are characterized by an excessive number of zeros, leading to bias in the estimated results. Given the proportions of the total observations for the three explanatory variables for which the observations are zero, the zero observations account for only a very small share of the number of observations for each of the three variables. For these reasons, the negative binomial fixed effects model and the negative binomial random effects model are used in the empirical analysis.

\section{EMPIRICAL RESULTS}

The basic model adopted in this paper investigates the impact of imports, exports, technology trade expenditure, revenue from technology trade and domestic R\&D expenditure on patents. In order to avoid the problem of endogeneity, all variables are lagged by one period. In considering R\&D expenditure, it is assumed that a country's investment in R\&D will not lead to innovation in the current period. Thus, it is necessary to decide on the number of periods by which R\&D expenditure should be deferred. The two models use domestic R\&D expenditure lagged one, two and three periods to examine which specification is better. The criterion on for superiority is based on statistical significance, with greater deemed to be better. The empirical results show that the use of domestic R\&D expenditure lagged one period is the best, indicating that the current domestic $R \& D$ will exhibit the effects of innovation in the following period. It is for this reason that in the following analysis, domestic R\&D expenditure is always lagged one period. 


\subsection{Results for cross-border patents}

The model is tested using the Hausman test, with the random effects model as the null and the fixed effects model as the alternative hypothesis. The null hypothesis is not rejected. Therefore, cross-border patents in the basic model are explained by random effects. Cross-border patents refer to the number of patents that are domestically owned but invented by foreign inventors, most of which are the result of cooperation in innovation between domestic enterprises and foreign employees of foreign subsidiary companies. They can reflect the ability to control domestically foreign inventions and inflows of foreign technology from abroad.

In what follows, we analyze the basic model for which cross-border patent is the explanatory variable. Both L1_Import and L1_export that are traded internationally are negatively and positively correlated, respectively, with patents at the $1 \%$ level. Thus, international trade has a significant impact on innovation cooperation, with exports enhancing and imports hindering innovation cooperation. In order to increase exports and improve their technological level, domestic enterprises will strengthen their controls over foreign innovation. As most of the countries comprising the sample are high income and highly developed countries, most of the domestic enterprises are engaged in technology-intensive industries, and the knowledge or technology that can be learned through imports is limited. Contact is made with foreign enterprises through exports, and in competition with them, cooperation in innovation is enhanced, causing technology to flow from abroad. It can be seen that the impact of imports hindering innovation cooperation is greater than the impact in exports enhancing innovation cooperation. If one wants to increase innovation cooperation, it is necessary to import technology at considerable cost. Moreover, reducing innovation only through cooperation requires not engaging in R\&D. Hence, the magnitude of the increase in innovation cooperation through increasing exports should be smaller than the reduction in innovation cooperation through increasing imports. Technology trade ( $L 1 \_T P$ and $L 1 \_T R$ ), which consists of directly exchanging knowledge and technology through licensing or purchases and sales between countries, is an important indicator to measure technology diffusion. The expenditure on technology trade and the income from technology trade, with each variable lagged one period, are positively and negatively correlated with patents, respectively, at the $1 \%$ level of significance. The volume of technology trade reflects the flows of technology, where greater expenditure on technology means the domestic country is more heavily engaged in investing in technology internationally, so that innovation cooperation will be encouraged. On the contrary, the larger is the income from technology trade, the more will countries accept the commissioning of invention work abroad. For this reason, there is a negative relationship with cross-border patents. However, regardless of whether they arise from income from technology trade or expenditure on technology trade, flows of technology are always seen to exist. The coefficient of expenditure on technology trade and that for income from technology trade are such that the magnitude of the positive effect on innovation being smaller than the negative effect. $L 1$ GERD is positively correlated with patents at the $1 \%$ level of significance. This variable measures the country's investment in $R \& D$, and indicates whether investment in domestic R\&D promotes innovation cooperation, and if the effect of the country's investment in domestic R\&D will be observed in the next period. The dummy variables are not significant.

\subsection{Results for jointly-invented patent}

The Hausman test rejects the null hypothesis of random effects, so that jointly-invented patents under the basic model are explained by fixed effects. Jointly-invented patents refer to the patents for which domestic inventors have cooperated jointly with at least one foreign inventor. As another approach to investigate patent cooperation, in what follows we analyze the basic model in which patents that are invented jointly with foreign countries are given as the explanatory variable. L1_Import is found to be negatively correlated with patents at the $10 \%$ level of significance. As the sample of countries consists of mostly high income and advanced countries in terms of economic development, the products imported by such countries are primarily low technology-intensive products. When faced with countries with relatively low technology, the incentive to engage in innovation cooperation is comparatively small. Hence, there is a positive (but insignificant) correlation between exports lagged one period and patents. Technology trade ( $L 1 \_T P$ and $L 1 \_T R$ ) exhibit positive and negative relationships, respectively, with innovation cooperation at the $10 \%$ and $1 \%$ levels of significance. Expenditure on technology trade denotes the extent to which the country domestically uses foreign technology, so that innovation cooperation exchanges between domestic and foreign research personnel are more frequent. In such circumstances, technology is disseminated internationally, but the income from technology trade leads to a significant reduction in innovation cooperation. The greater is the income from technology trade, the greater is the degree of domestic innovation, so there is a tendency for foreign countries to purchase the domestic country's technology. For this reason, in the case of research personnel in countries owning a relatively large amount of technology, there is relatively little incentive for them to engage in innovation cooperation with foreign research personnel. The coefficient of expenditure on 
technology trade is 0.156 , and the coefficient for income from foreign trade is -0.279 . This also shows that the magnitude of the positive impact on innovation is smaller than that of the negative impact. L1_GERD exhibits a positive relationship with innovation cooperation at the $1 \%$ level of significance. In order to promote innovation cooperation, it is necessary to promote investment by the domestic country in $R \& D$, and the effect of investment in the current period will be felt in the following period. The dummy variables are not significant.

Based on the above, cross-border patents are relatively more significantly influenced by foreign trade and technology trade. Both cross-border patents and jointly-invented patents are affected by domestic R\&D expenditure, resulting in technology diffusion and an increase in innovation activities. For this reason, in the next section we decompose $R \& D$ expenditure by sector, and discuss the respective impacts of $R \& D$ expenditure of different sectors on innovation cooperation and innovation activities.

\subsection{Decomposition of $R \& D$ for Cross-broader patents}

The estimation results for the model in which $\mathrm{R} \& \mathrm{D}$ is decomposed are available on request. This model decomposes domestic R\&D expenditure into corporate $R \& D$ expenditure, government department $R \& D$ expenditure, and higher education R\&D expenditure, and each of the variables is lagged one period. The dependent variables are cross-border patents and jointly-invented patents. The models use the fixed effects and random effects models. The Hausman test does not reject the null hypothesis, so that the random effects model is used. Imports and exports lagged one period exhibit a negative and positive relationship with patents, respectively, at the 1\% level of significance. Expenditure on, and income from, technology trade are positively and negatively related to patents, respectively, at the $1 \%$ level of significance. The results can be explained in a similar way to those for the basic model, as given previously. Corporate R\&D expenditure and higher education R\&D expenditure, each lagged one period exhibit positive relationships with patents at the $5 \%$ significance level, while government $R \& D$ expenditure lagged one period is positively related to patents, but is insignificant. As cross-border patents are essentially the result of innovation cooperation between the research personnel of domestic enterprises and of foreign subsidiaries, domestic R\&D expenditure is affected by the enterprises' corporate $R \& D$ expenditure. The more that an enterprise invests in $R \& D$, the more it can learn about what it lacks. For this reason, through the foreign inventor's ability to innovate, the domestic country's technology can be encouraged to grow, and technology will flow to the domestic economy from abroad. Investment by countries in human capital is also important as enterprises that need highly-skilled talent in technology and knowledge have the ability to cooperate in innovating with foreign researchers. The coefficient for higher education R\&D expenditure of 0.664 , and for corporate R\&D expenditure is 0.169 , indicating that the positive impact of the higher education on innovation cooperation is greater than the positive impact of corporate R\&D expenditure.

\subsection{The jointly-invented patents effect of $R \& D$}

The jointly invented patents with a foreign country will serve as the explanatory variable in the R\&D model decomposed by sector. The estimated results of the analysis are as follows. Imports lagged one period exhibit negative correlation with patents at the 5\% significance level, while exports lagged one period exhibit positive (but insignificant) correlation with patents. Expenditure on, and income from, technology trade exhibit positive and negative relationships with patents at the $5 \%$ and $1 \%$ levels of significance, respectively. The results of this analysis are by broadly the same as for the basic model, which were discussed above. Corporate R\&D expenditure lagged one period and government agency R\&D expenditure are both insignificant, with higher education R\&D expenditure exhibiting a positive relationship with patents at the $1 \%$ level. Thus, when an inventor in the domestic country engages in innovation cooperation with a foreign inventor, expenditure on R\&D will tend to be more concentrated in expenditure on R\&D in higher education, reflecting the importance of education in human resources. The extent to which knowledge and technology can be used depends on the ability to understand and interpret such knowledge and technology. In order to increase cooperation in innovation between foreign and domestic research personnel, it is necessary to raise the level of knowledge in the domestic country.

\section{ACKNOWLEDGMENTS}

For financial support, the first author wishes to thank the National Science Council, Taiwan, and the second author is most grateful to the Australian Research Council and the National Science Council, Taiwan. This paper was completed during a visit by the first author to the Erasmus School of Economics, whose hospitality is greatly appreciated. 